Series in Asian Labor and Welfare Policies 
Series Editors:

Chris Chan

Dae-oup Chang

Khalid Nadvi

Asia has been the new focus of global social sciences. One of the key features for the rise of Asia is the creation of the largest industrial workforce in the human history. China, India and many other newly industrialized countries in Asia have been transformed as 'world factories' for the global capitalism in the past four decades. This development involves both extensive and intensive migration of labour across Asia. Massive populations in the Asian countries, who formerly involved in traditional self-subsistence activities, have become wage labourers. In China itself, more than 260 million of rural-urban migrant labours have been created in the past three decades.

The production and the reproduction of labour in Asia have therefore become the major research themes in a wide range of disciplines such as gender studies, development studies, policies studies, employment relations, human resource management, legal studies as well as sociology, politics and anthropology.

More information about this series at http://www.springer.com/series/14486 
Lin Chen

\section{Evolving Eldercare in Contemporary China}

Two Generations, One Decision 
Lin Chen

Fudan University

Shanghai, China

ISBN 978-1-137-54693-7

Series in Asian Labor and Welfare Policies

DOI 10.1057/978-1-137-54440-7

Library of Congress Control Number: 2016935071

(C) The Editor(s) (if applicable) and The Author(s) 2016

The author(s) has/have asserted their right(s) to be identified as the author(s) of this work in accord-ance with the Copyright, Design and Patents Act 1988.

This work is subject to copyright. All rights are solely and exclusively licensedby the Publisher, whether the whole or part of the material is concerned, specifically the rights of translation, reprinting, reuse of illustrations, recitation, broadcasting, reproduction on microfilms or in any other physical way, and transmission or information storage and retrieval, electronic adaptation, computer software, or by similar or dissimilar methodology now known or hereafter developed.

The use of general descriptive names, registered names, trademarks, service marks, etc. in this publication does not imply, even in the absence of a specific statement, that such names are exempt from the relevant protective laws and regulations and therefore free for general use. The publisher, the authors and the editors are safe to assume that the advice and information in this book are believed to be true and accurate at the date of publication. Neither the publisher nor the authors or the editors give a warranty, express or implied, with respect to the material contained herein or for any errors or omissions that may have been made.

Printed on acid-free paper

This Palgrave Macmillan imprint is published by Springer Nature

The registered company is Nature America Inc. New York 
To My Parents 



\section{Preface}

I deeply appreciate all the elders and their children for graciously agreeing to participate in this study, answering difficult questions, and probing their memories. To protect their identities and anonymity, their names are all pseudonyms.

Lin Chen

Shanghai, China 



\section{ACKNOWLEDGEMENTS}

I have a lot of people to thank for this book. First and foremost are my parents. The map for my academic pursuit was laid out by following my father. He defined a kind, elegant, and sophisticated person and an ophthalmologist with excellent professional competence. Observing his care for his patients all my life, I have witnessed and lived some of the most enduring, fundamental, and treasured virtues in humanity. He suffered from lymphoma and passed away in 2011. However, he dealt with the disease courageously, quietly, and privately, and conducted himself with enormous grace and made it into an opportunity for me to grow and be human. My mother is the most loving and caring person I have ever known. During my father's decline and death, she remained the backbone of our family. My mother is more important to this book than she knows. This is why I dedicate this book to my parents.

I am indebted to my mentor at UCLA, Lené Levy-Storms. She genuinely cared about my research and professional development. If she had not kept pushing my boundaries and challenging my preconceived notions of what I was capable of, I would have not become the researcher and person I am today. I was also truly blessed by the dissertation committee who walked me through this study: Dr. Laura Abrams, Prof. Ted Benjamin, and Prof. Marjorie Kagawa-Singer.

Felicia F. Tian introduced me the opportunity to develop a book proposal for Palgrave Macmillan-what has become this book. Sharing the journey of becoming faculty at Fudan, Felicia is not just a colleague but a true ally. 
Skylar Lenox, my family in Los Angeles, I thank you for editing my book and our times in Moorpark. (And Finn!)

I thank those at Palgrave Macmillan who supported and advised me from book proposal to the final manuscript: Veronica Goldstein, Rachel Krause, Alisa Pulver, Milana Vernikova, and Sara Crowley Vigneau.

Finally, I thank the following for permission to use extracts:

Sage Publications:

Chen, L. (2015). Decisions for institutionalization among nursing home residents and their children in Shanghai. Qualitative Health Research, 25, 458-469. doi: 10.1177/1049732314551990

Taylor \& Francis Group:

Chen, L. (2015). Deciding to institutionalize: Caregiving crisis, intergenerational communication and uncertainty management for elders and their children. Journal of Gerontological Social Work, 58(2), 128-148. doi: $10.1080 / 01634372.2014 .925026$ 


\section{Contents}

1 Introduction 1

1.1 History of Chinese Sociodemographic Changes 2

1.2 Long-Term Care in the USA and Urban China 3

$\begin{array}{lll}1.3 \text { Study Purpose and Significance } & 7\end{array}$

1.4 Outline of the Book 9

References 9

2 The Setting: The Nursing Home and Its Sociocultural Context in Urban China $\quad 15$

2.1 The Nursing Home 15

2.2 Current Nursing Home Care

2.3 The Social Context Related to Nursing Home Care in Urban China 20

2.4 Research Gaps in Deciding to Institutionalize 29

2.5 Conclusion 31

References 32

3 The Theoretical Lens: Conceptualizing the Decision-Making Process 41

3.1 Crisis Theory 41

3.2 Intergenerational Communication 43

3.3 Uncertainty Management Theory 46

3.4 The Life Course Perspective 48 
3.5 Conceptual Framework 51

3.6 Conclusion 53

References $\quad 54$

4 Unexpected Reality: Etiology of Family Caregiving 59

4.1 The Unexpected Reality of Co-Residence 59

4.2 The Caregiving Gender Paradox 62

4.3 Discordance Regarding Caregiving Tradition 64

4.4 Trying Out Caregiving Alternatives 66

4.5 The Family Caregiving Context 67

4.6 Conclusion 69

$\begin{array}{ll}\text { References } & 70\end{array}$

5 Intergenerational Negotiation: A Power Play 73

5.1 Who Initiated the Decision? 73

5.2 Seizing Remaining Decision-Making Autonomy $\quad 75$

5.3 Preempting Caregiving Depletion 78

5.4 The Last Straw: "We Had No Choice.
They Had No Choice"

5.5 Family Caregiving Crises $\quad 84$

5.6 Spatially Situated Caregiving Decision-Making Dynamics 85

5.7 Unbalanced Power Relations 87

5.8 Accommodated Intergenerational Communication 89

5.9 Conclusion 91

References 91

6 Children Parenting: First and Last Adventure 95

6.1 Uncertainties About Nursing Home Care
Between Generations

6.2 Managing Uncertainties About Nursing Home Care 98

6.3 Life in the Nursing Home 101

6.4 Different Uncertainties About Nursing Home Care Between Generations 103

6.5 Nursing Home Care and Elders' Self-Determination 104

6.6 Conclusion 105

References 106 
7 The End of an Era: A New Dialogue

7.1 Parents of the Only Child

7.2 Chinese Baby-Boomers' Vision of Ideal Long-Term Care

7.3 Being a Chinese Baby-Boomer

7.4 Conclusion

116

References

8 Conclusions

8.1 Caregiving Decision-Making

8.1.1 Age-Distinctive Decision-Making Dynamics

120

8.1.2 Filial Piety and the Decision to Institutionalize

122

8.2 Theoretical Implications

123

8.2.1 Crisis Theory

125

8.2.2 Intergenerational Communication

8.2.3 Uncertainty Management for Nursing Home Care

8.2.4 The Life Course Perspective

8.3 The Dyadic Perspective on Caregiving 129

8.4 Practice and Policy Implications

8.4.1 Implications for Social Work Practice

8.4.2 Long-Term-Care Policy Development in China

8.5 Informing the Next Step

8.5.1 Research on Decision-Making Dynamics

8.5.2 Utilizing Long-Term Care

8.5.3 Evolving Intergenerational Relationships

8.5.4 Other Sociocultural Factors

Appendix 3: Synopsis on the Decisions for Institutionalization Among the 12 Families 
xiv CONTENTS

Appendix 4: Data Analysis: Codebook 169

Appendix 5: Data Analysis: Significant Statements and Related Formulated

Appendix 6: Methodological Implications

Appendix 7: Study Limitations

Bibiliography

Index 


\section{List of Figures}

Fig. 1.1 Available long-term care in the USA and urban China

Fig. 5.1 Families categorized by which generation initiated the decision to institutionalize and their primary reasons (previously published in Qualitative Health Research)

Fig. 5.2 A Cartesian coordinate system of the 12 dyads' experiences of deciding to institutionalize (previously published in Qualitative Health Research) 



\section{LIST OF TABLES}

Table 1.1 Types of long-term care in the USA 5

Table 3.1 Four preliminary propositions 52

Table 5.1 Major factors in the decision-making process to institutionalize in the 12 families $\quad 74$

$\begin{array}{lll}\text { Table 8.1 } & \text { Four modified propositions } & 124\end{array}$

Table A.l Demographic and health characteristics of participating elders $(\mathrm{N}=12)$

Table A.2 Participating children's relationships with their parents $(\mathrm{N}=12)$

Table A.3 Data analysis: codebook

Table A.4 Data analysis: significant statements and related formulated meaning 
